\title{
Teaching Literature to Foreign Language Learners: A Medium to Bridge the Gap between Cultures
}

\author{
Huda Al-Tamimi \\ Centre for Arab and Islamic Studies (The Middle East and Central Asia) 2012 Huda Al-Tamimi, Centre for Arab and Islamic Studies (the \\ Middle East \& Central Asia), The Australian National University, Canberra, Australia
}

\begin{abstract}
As the increase in the pace of globalised communications enables s econd-language (L2) students to become more proficient and enthusiastic about their learning, teaching literature in the target language has taken new relevance and importance. A growing body of evidence indicates that teaching literature to $\mathrm{L} 2$ learners can provide a number of valuable outcomes, including helping students to understand and appreciate other cultures different from their own. Literature provides useful examples of syntax and language usage in different genres, introducing a level of enjoy ment to the learning experience and encouraging L2 learners to pursue additional readings in the target language. The opportunity for immersion in the target culture takes the students to another level of appreciation of the culture and civilisation of the target language. To determine how these desirable outcomes can be implemented in second-language classrooms, this paper provides a review of the relevant scholarly literature concerning teaching literature to L2 learners in general and as a medium to bridge the gap between cultures in particular. Examp les of the use of literature in the author's Arabic language classes are provided throughout. A summary of the research and important findings are presented in the conclusion.
\end{abstract}

Keywords Arabic Language, Arabic Literature, Pedagogy, Second Language Learners, Cultural A wareness, Linguistic Competency

\section{Introduction}

This paper will examine the role L2 literature courses can play in bridging the cultural gap between L2students and the target language community. It will also discuss how teaching literature can help students become more effective communicators in the target language. As the author is a long-standing lecturer of Arabic as a second language to Anglo-Saxon students, this paper will demonstrate the role A rab literature classes can play in improving students' cultural-linguistic competence in and empathy towards that language and culture. Like Hymes at[1], Kitao at[2] and Alptekin at[3], this study argues that effective communication requires language proficiency and cultural competence in equal manners. Cultural competence refers to an empathetic understanding of the values, beliefs and perceptions of the target culture combined with the ability to act in accordance with culturally defined norms and expectations. This research will also show that language proficiency and cultural competence both constitute and are constituted by each other and that it is impossible to achieve functional fluency in one without also achieving functional fluency in the other. The paper will argue that, if done well,

* Corresponding author:

huda.al-tamimi@anu.edu.au (Huda Al-Tamimi)

Published online at http://journal.sapub.org/edu

Copyright (C) 2012 Scientific \& Academic Publishing. All Rights Reserved the study of literature will lead to increased empathy with and respect for the language community, improve student's motivation and make them more effective communicators in the target language.

The Arabic word for literature is adab (أدب). It springs from a word that means etiquette and culture and signifies politeness, sophistication and enrichment. Arabic literature emerged in the 6th century. Arabic now comprises a rich literary corpus that spans sixteen centuries and includes a wide range of genres from different eras and geographical zones. Arabic is a Semitic language that is spoken by at least 250 million people around the world. There are two standardised written variants of the Arabic language, Classical Arabic and Modern Standard Arabic[4]. The former is the orig inal language used in the Holy Qur'an, the sacred text of Islam, whereas the latter is a modernised version that is used in media. The two variants are very close. Arabic is a diglossic language, which means that the written variants of the language are not actually spoken by any members of the language community in normal day-to-day situations. The numerous spoken variants of Arabic a re not standardised and are generally not used for writing. They are often referred to as dialects and can diverge significantly from the written forms [5].

Historically, the Arabic-speaking world has made significant contributions to global philosophy, science and literature and continues to do so today. Its dominant faith, Is lam, has played a central role in world history for centuries. 
Most second-language students in the West, however, are unaware of the historical and global significance of Arabic or Is lamic culture. Especially since the $9 / 11$ terrorist attack on the US World Trade Center, these students are exposed on a daily basis to explanations and descriptions of Arabs and Muslims that are, at best, one-sided. These biased and ill-informed accounts of the cultural practices of Arabic speakers and Muslims generally do little to help language students empathise with, or understand, members of the language community. This study will argue that active engagement with Arabic literature can help students gain a perspective on the Arabic speaking community that is more in line with how Arabs perceive themselves. Conversely, reading literature can also help Western students comprehend the fears and concerns some Arabs feeltowards Israel or the United States. Furthermore, this paper will argue that reading Arabic prose and poetry can improve students' fluency and help them become more effective communicators.

\section{Language Proficiency and Cultural Competence}

A mistaken view that continues to dominate L2 teaching is the idea that a language is an "autonomous construct," independent from the people that speak it. It is the belief that language is simply a code and that "one language is essentially (albe it not easily) translatable into another"[6]. This view holds that foreign-language teaching should focus primarily on ensuring that students master the vocabulary and the grammatical rules of the target language. Educators who adhere to th is perspective are not necessarily opposed to teaching the culture of the people who speak the language but regard this merely as "yet another skill at the disposal of those who aspire to become conversant with the history and life of the target community"[7]. This is however worse than an underestimation of the importance of teaching culture; it demonstrates a complete lack of understanding of what it means to be truly proficient in a language. This paper will show that cultural awareness is an integral part of linguistic competence.

Language is not an "autonomous construct" but is a system influenced by various socio-political processes [8][9]. The systems of classification, address and reference forms, specialised lexicons and metaphors used in a language portray an often forgotten or hidden struggle over the symbolic power of a particular way of communicating [9]. Language is "a key to the cultural past of a society" [10] and 'a guide to 'social reality'[11]. Sapir argued that "language does not exist apart from culture, that is, from the socially inherited assemblage of practices and beliefs that determines the texture of our lives"[11]. As one of the Literature course student reflected on his experience:

“... I think studying literature gives a fascinating insight into a culture and its language. The pre-Islamic poetry and writing by Abu Nuwas and the Andalusians were particu larly interesting, as much modern Arabic/Muslim propaganda tries to gloss over the subversive and dissenting elements of Arabic culture. It would be interesting also to see some literature from non-Muslim Arabs (Christians, Druze etc) who make/made up a large percentage of the Arabic population...."

Ever since the $7^{\text {th }}$ century, the Holy Qur'an has had a great influence on Arabic culture and language. We encounter culture-specific associations and meanings in the Holy Qur'an that have shaped the perceptions and understandings of native Arabic speakers for over fourteen centuries. Some of these associations are shared by other speakers. A clear example of this is the emotional perception of colours. For example, English speakers and Arabic speakers have very similar emotional associations with the colours black and blue. The following verses from the Holy Qur'an show clearly how these two colours are perceived:

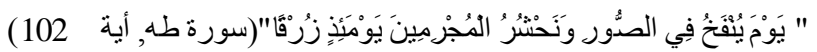

(Qurán: Taha: 20/102)

Translation:

"...And those on the Day of Judgment, you shall see the faces of those who related falsehood to God, how they will assume blueness expressive of the terror that falls upon them...."

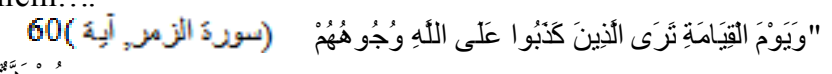
مُسْوَدَدة "

(Qu rán: ALZu 'mar:39 /60) 60(

Translation:

“...The Day shall come when the trumpet is sounded and We throng the sinful who shall look blue, being affected with terror, distress and anxiety...."

Another colour that poses similar connotations between the Islamic and Christian cultures is green. The colour green symbolizes nature and life and it is used in the decoration of mosques, the bindings of Qurán, and in the flags of various Muslim countries. In Christianity, green means hope and growth; it symbolizes the breaking of shackles, fertility and represents bountifulness, hope and the victory of life over death. In general, the colour green is primarily associated with plant life and as a symbol of natural growth and life. The exception is its use in Leviticus to denote disease. For example:

"describing a meat offering" - Leviticus 2:14

"describing edible plants" - Genesis 1:30; 9:3, II Kings 19:26, Job 39:8, Psalm 37:2

"trees" - Exodus 10:15, Deuteronomy 12:2, I Kings 14:23, 2 Kings 16:4; 17:10, II Chronicles 28:4, Psalm 37:35; 52:8, Is aiah 37:27, Jeremiah 2:20

These examples only references verses in which the color is used consistently amongst Bible translations, therefore the references are not exhaustive and only demonstrate the plain use of the colour in a passage. These examples, along with others, were presented to students in a lecture which led to a great deal of discussion and association in regard to the similarities and differences between Western and Arabic culture. It was only introduced to make a comparison 
but it went further in piquing their interest in learning about the Holy Qur'an and Islamic and Arabic cultures. A number of students evolved the discussion into more detailed research projects investigating issues of interest to them as one student commented for such comparison:

“... Both are very varied with their own classic cannon, and fundamentally influenced by religious writing (Arabic has the Koran, English has the King James Bible and the Book of Common Prayer) - I'm sure that similar themes could be found and compared.... "

The projects were later presented in class in both oral (30-45 minutes) and written (4500 words in Arabic) forms.

Language and culture are so closely interwoven that their boundaries, if any, are extremely blurred[7]. Many people think of culture as what is often referred to as "high culture"-art, literature, music, and so on (ibid). However, contemporary social scientists define the concept more broadly. For example, Peck defines culture as "all the accepted and patterned ways of behaviour of a given people."[12] This includes visible external behavioural patterns and tangible or material manifestations such as town planning, advertisements and forms of "high culture." However, a significant part of culture is neither directly visible nor tangible. Sapir wrote that "culture may be defined as what a society does and thinks"[11]. He argued that language plays a key role in structuring the thought patterns of its speakers, calling it the "how of thought"[11]. He wrote that "language and our thought-grooves are inextricably interrelated, are, in a sense, one and the same"[11]. This is in line with the famous French sociologist Durkheim who argued earlier that "language is not merely the external covering of a thought; it is also its internal framework. It does not confine itself to expressing this thought after it has once been formed; it also aids in making it"[13]. A significant part of culture, then, operates at the internal, often subconscious, level and is shaped by the very language people use. This includes values, ways of perceiving things and thought patterns [14]. As we will see, a people's "high culture" is a tangible manifestation of this invisible part of culture and therefore constitutes a window for $v$ iewing the ways of thinking, seeing and valuing of that particular people.

Second-language teachers should help students understand that culture predisposes people to a certain worldview and that language plays a key role in this: language maintains and sanctions a particular cognitive framework[15]. Specific socio-culturally structured associations vary from culture to culture and need to be learned and "internalized"[16]. To give an example: English speakers have learned to perceive a connection between red roses and romance. Clearly, this is a cultural perception, as there is no natural link between the two particularly. Similarly, Arabic speakers have learned to perceive a connection between swords and time, hence the proverb 'time is a sword' (افيسلاك تقول). Different language communities perceive different associations. Language can condition people to see and hear things in certain ways [17].
Foreign-language learning can, therefore, not be separated from foreign culture learning. It is essential that "... knowledge of the grammatical system of a language be complemented by an understanding of culture-specific associations and meanings...."[18]. A cultural linguistic system comprises various elementary meaning units (EMUs) which may differ from EMUs that operate in other systems[19]. One example of such an EMU would be that of the association between roses and romance that exists in the minds of English speakers, discussed above. Lado regards familiarity with a culture's EMUs “... necessary for full communication with natives, to understand their reports on great achievements, and to read their classics...."[19]. Indeed, Politzer warned that “... if we teach language without teaching at the same time the culture in which it operates, we are teaching meaningless symbols or symbols to which the student attaches the wrong meaning...."[20].

There are direct prag matic reasons for teaching culture as an integral part of foreign-language teaching. In order to become functionally proficient in their new language, students need to understand the role of context and the circumstances under which language can be used accurately and appropriately. As an example, the author's students were given the task of reading 'The Bad Boy 'جاء), يقشّا) a wine poem (khamriyya) of Abu Nuwas (he was of Persian origin). He liked to shock society by openly writing about things which Is lam forbade - still; his poetry was considered among the best literary works both during his time and by future generations. The poem opened a whole new discussion on Arabic/Islamic culture, and was written in a highly complex register that was surprisingly well managed by the students.

\section{دلبلا مز امخن ع لأسدأ تجعو هلئاسي للطى لـ يقشاء جاء}

The translation of this verse is that the poet has changed the classical way of poem's opening verse where the poet usually remembers and cries (يسائلة) for the place (طلل) where his beloved used to live. Abu Nuwas' described the classical “Arab poets" ( الثقي as wasting their time crying on lost love while he looks (عجت) and ask (أسأل)for the city's pub (أبلا) gniyojne dna lohocla gniknird yb emit doog a evah ot the company of waitresses there.

The students reflected in their essays on their introduction to literary works and noted it in their course evaluation. For example, a student commented on the course that:

"... It is challenging, stimulating and encouraging for open discussions and debates...."

The student further commented that the course material opened an authentic image of the culture and the society behind the target language. Another commented on the opportunity to be exposed to a high level language register as opposed to the shallow and superficial language textbook themes. The student went on to describe how reading and discussing the early Islamic era provided an opportunity to investigate the real Islam and what it calls for. In his essay he argued that Islam is much more than what is portrayed in the media and the West. The basic aim of the course is to give students an opportunity to have access to short, readable 
literary and Islamic texts such as verses from the Qur'an that would give them a rounded and balanced view of the field of Arabic literature. This provides them with a footing from which to seek out research topics, and can guide the $m$ in their choices of more advanced courses. For example, one student investigated the philosophy of the Islamic scholar Al-Ghazali and his interpretations of Sufis m. Other students were interested in learning about how love, wine, war and wo men, etc., are portrayed in the course material and take a step further in their own research essay. Another student reflected on her feelings towards the course by saying:

“... Through studying Arabic/Islamic literature, I gained an insight into the emotive use of the Arabic language. The Arabic language used in the literature we studied was not only poetically engaging but very symbolic and open to interpretation due to its metaphorical imagery. This imaginative aspect of the language was therefore better understood through the literature studied. Whilst different periods within Arabic literature displayed different characteristics, studying Arabic/Islamic literature is a way in which students can understand the use of the language to express emotion. This then allows students to further understand the unique cultural and religious aspects of Arabic society, an understanding which is not as easily gained through other means of learning. The complexity of the Islamic culture is further understood through the examination of Arabic literature, as it allows the Western student to contextualize the expression of such fundamental cultural and re lig ious characteristics...."

Successful communication requires competent participation in the cultural linguistic community. For this reason, it is vital that students should, at the very least, learn what constitutes conventional behaviour in common situations. If students are to establish themselves as competent participants in their new language community they need to consistently display the "correct" behaviour and perform the "correct" exchanges of language in any given social situation[21]. To this end they need to become fully conversant with their new language community's cultural knowledge. Cultural linguistic knowledge is "the community's store of established knowledge"[22]. It is "an all-encompassing kind of knowledge which, to a certain extent, determines, facilitates or precludes, all other types of knowledge" in that community[7]. It shapes "not only what the members of a cultural linguistic commun ity should think or learn but also what they should ignore or treat as irrelevant"[23]. It comprises procedural knowledge for "correctly" performing activities such as answering the phone, asking for a favour, cooking, and weaving [24], as well as strict "structures of expectation"[25] with which everyonebelonging to the cultural-linguistic community is expected to comply without error. Samovar et al argue that culture "... is the foundation of communication" for it dictates who talks to whom, about what, and how the communication proceeds[26]. It also shapes "how people encode messages, the meanings they have for messages, and the conditions and circumstances under which various messages may or may not be sent, noticed, or interpreted ..."[7]. Teaching a culture is, then, an equal complement to teaching a language. It is not an optional "extra" but a vital part of helping students become proficient in their new language.

\section{Cultural Competence, Objectivity and Respect}

The teaching of culture in the foreign-language class-room is often limited to the transmission of factual cultural information. Students are, for example, presented with statistical information about the country or given talks about the target language community's institutions, customs, habits, and folklore[27]. For example, Spanish language students tend to be presented with lectures or articles about the Spanish cuisine, Flamenco dancing, the Catholic Church and bull-fighting. Although this is valuable information which would benefit those students who wish to acquaint themselves with these topics, on its own it will do little to help students understand and empathise with that culture's way of life, values, attitudes and beliefs. All that it offers is "mere book knowledge learned by rote"[28].

The Arabic/Islamic literature studied by the author's students represented more complex symbolism than that which can be achieved through the use of the English language in Western secular literature. In this way, the teaching of Arabic/Islamic literature differs from the teaching of Western secular literature. Whilst common themes of war and love feature prominently in both literatures, the teaching of Arabic/Islamic literature is inherently more challenging for students which then leads to a deeper engagement with the literature. Furthermore, Arabic/Islamic literature is far less constrained by grammatical rules than Western secular literature which allows students to be less strict in interpreting the meaning and messages of the literature studied. If students are to understand members of the target language community they need to be able to step into their shoes and experience the invisible part of that community's culture. Educators cannot teach this part of culture any more than they can teach anyone how to breathe[7]. It would be quite wrong to teach students to think about and perceive things in a specific way: such an approach "is corollary and ancillary to cultural and linguistic imperialis m" (ibid). It is vital that educators do not teach the foreign culture from an outsider's perspective. Instead they should enable students to immerse themselves in the foreign culture by turning the classroom into a "cultural island"[27],[29] and[12]. Literature offers a great opportunity for such immersion for it constitutes a framework of authentic symbols, values and meanings. Under this approach, the second-language teachers should act as cultural mediators, alerting students to aspects of the target culture that are of importance to the members of the target community themselves. They should help students make links between the target culture and their 
own[27] and make students aware of, and help them reflect upon, any preconceived ideas they may be holding about the target culture[29].

If done well, cultural-linguistic instruction will also garner empathy and respect towards the language community and promote objectivity and cultural understanding[7]. As shown above, communication is not just an exchange of information but a highly cognitive, affective and value-laden activity that both shapes and is shaped by socio-political processes. For this reason, Melde argues that second-language teaching should foster "critical awareness" of social realities[30]. Many second-language students have little or no systematic knowledge about their own membership in a given society and culture and will therefore struggle to interpret the cultural phenomena they find in the language they are studying[27]. Students should be made aware that cultural factors, such as age, gender, or social class, shape cultural-linguistic interactions in all societies, including their own. Educators should help students understand that "... by the very act of talking, people assume social and cultural roles, which are so deeply entrenched in their thought processes as to go unnoticed...." [7]. When teaching culture in a foreign-language class room, it is important to start by raising students' awareness of their own culture and the ways in which this shapes how they themselves see, value and judge the world around them. Discussing the values, expectations, traditions, customs, and rituals they subconsciously take part in, helps students reflect upon the values, expectations, and traditions of others "with a higher degree of intellectual objectivity"[31]. The method used by the author to teach Arabic/Islamic literature was a combination of student-based learning which comprised students reading literature out loud in a classroom context, presentations to peers, and group translation, all guided by the teacher. The chronological order in which the Arabic/Islamic literature is taught allows students to develop an understanding of the importance of rhetoric in traditional Arabic culture and the use of metaphors as it developed over time. The imagery which students can discover and appreciate from the study of Arabic literature is best enabled by promoting this student-based learning.

Learning a foreign culture can be subversive of the assumptions and premises that operate in a student's native culture[31]. Second-language students may experience cognitive dissonance when they seek to integrate the values and meanings of the foreign culture with that of their own[18]. They may find, for example, that they suddenly understand two different "truths" that are in direct conflict with each other. As Kramsch points out, “... from the clash between the native culture and the target culture, meanings that were taken for granted are suddenly questioned, challenged, problematized...."[27]. The result of this is that the student de-centers his or her worldview. This shift of perspective is conducive to intellectual objectivity and increased empathy and respect for the target language community. Educators should guide students in th is process as cultural mediators and aim "... to increase students" awareness and develop their curiosity towards the target culture and their own...."[32]. Literature can be used to great effect in this context. If done well, teaching culture in the foreign-language classroom helps students understand the superficiality of such things as superior and inferior cultures, and that there are differences among people within the target culture too[7].

\section{Selecting Literary Texts}

Which literary texts to use in a second language course is a decision that should be contingent upon a variety of factors within each course. The worst thing that an educator can do in this regard is to make a standard list of literature to be covered in every class without regard to the position of the students. In the case of Arabic literature, one must take into consideration that the Arabic language is very challenging for Western students and therefore a variety of methods are needed for best learning techniques. Student-based learning is a relatively successful method for teaching Arabic/Islamic culture in a Western context as it forces students to engage directly with the material and express their understanding.

However, a combination of methodologies is needed for a comprehensive understanding of the language due to its multi-faceted nature, particularly in terms of correct syntax. This is something that cannot be fu lly understood by students via studying literature. While this may work in the traditional teaching of literature, where the focus is on the literature itself, it is not an effective method for the second-language course, where the ultimate goal is to have the students learn the language and its culture. While it may be possible that some of the classical literature pieces of the target language may be used in teaching second-language learners, a text should not be included in the curriculum for the simple fact that it is a classic, or otherwise culturally significant. As it has been correctly stated, "when selecting the literary texts to be used in language classes, the language teacher should take into account the needs, motivation, interests, cultural background and language level of the students"[33].

Such considerations were taken into account in choosing appropriate texts and resources for the courses the author taught at the Australian National University. The course material and the selection of texts were designed for students who had completed two and a half years of Arabic language courses at the Australian National University or its equivalent. The selection of material was carefully distributed over one semester to cover literature from the pre-Islamic era to the present time. The course had a particular emphasis on the development of students' understanding and appreciation of literature and cultural aspects of the Arabic language, aiming to expand their knowledge of specific literary eras of Arabic progression and uses over time. The key principle of teaching the course content is to have the students read the text/s and then study the content and vocabulary each week before attending the 
lecture to ensure maximum comprehension.

The sequence of the learning experience in this course moved in a logical and systematic manner. For example, the introduction of the pre-Islamic era dealt with the purposes of poetry and prose by introducing the main poets of that period and making comparisons with Western equivalents. It is mainly a case-based learning approach which reflects on each student's past experiences of his or her native language and literature. Therefore, when it comes to choosing which literary work to include, a variety of texts should be held in reserve.

Those who are opposed to using literature are correct when they point out that students might have little interest, and are concerned that this will result in avoidance and poor performance. Such negative results should not be the case and are completely avoidable — but not by leaving literature out of the curriculum altogether. A good method of picking literature for the class is to get to know the students and create a narrowed list of works that they may be interested in. Then present the students with a basic summary of each text, to spark their interest, and allow the final decision to be up to them. For example, they can vote on which literary work they would like to study-this not only ensures that the material used is correct for that class, but serves to increase their interest in that they will be more eager to study a text that they have chosen to read.

The process of selecting Arabic literature texts is greatly eased by following the above procedure, and what would otherwise be a sifting of literature spanning over almost two millennia becomes much less stressful. In order to properly pertain to the origins of Arabic literature, one must include some pre-Islamic and post-Islamic literature. The latter could cover important evolutionary ages of the Umayyad and Abbasid dynasties, and it is essential to include Islamic literature, in which the Qur'an was the largest influence. The importance of including these lies in the fact that these texts, especially the Islamic ones, are embedded in the Arab culture, irrespective of religion. The use of colloquial phrases such as Mashallah (as God wills it) or Inshallah (God willing) or the Arabic greeting Assalam-u-aleikum might stem from Islamic orig ins, but are now used by all Arabic speakers and not just Muslim Arabs; therefore these texts are aiding the use of the modern day variant of the language. It is important also to examine literature from more modern times which provides insight into the political and social machinations of society. A great example of this is Alaa al-Aswany's seminal novel Amarat Yacoubian (The Yacoubian Building) (2000). It not only uses modern-day Arabic but also portrays a multi-faceted-if often fictional-view of Egyptian society.

\section{Teaching Literature to Second-Language Learners}

This research argues that cultural linguistic immersion is the optimal way of achieving functional fluency in the target language and culture. When it comes to learning a new language there can be no substitute for actually living in a country where this language is spoken. However, L2 teachers can provide the next best thing by tuming their courses into cultural hub where students can engage themselves actively with the culture and the language they are studying. A student commented:

"... I think that my experiences in Arabic literature were as good as could have been expected within Australia. I felt the methodology used was helpful in leading us into an acute understanding of Arabic literature's history, and the teaching method was helpful from day one. While the intensive vocabulary was difficult to absorb in each text, the teaching was such that there was enough time to effectively run through the translation as well as the finer contextual points before truly analyzing the literature itself. I think other than doing a similar course in an Islamic/Arabic country, my experience in Arabic literature was as good as it could have been...."

The emphasis in class should be on '... cultural experience....' rather than '...cultural awareness ....'[18]. It is the author's experience that teaching literature is a great way of motivating students and drawing them in. Contrary to the view of some critics [34] who argue that teaching literature limits students to taking a passive role, this paper contends that teaching literature in fact stimulates students to engage proactively with the target language. As Duff and Maley point out, "literature offers universal themes which are relevant to students' own experience[35]. It, unlike many teaching inputs, is also a mirror that reflects and heightens each learner's perception of the social world. Thus, literary texts are open to multiple interpretation and genuine interaction". Students cannot remain passive if they are to interpret and understand what they are reading. They are placed "in an active interactional role in working with and making sense of the target language"[36]. Guided by the teacher, students must actively participate in "content-based purposeful learner talk" in order to discern meaning [37].

Critics may ask why students should specifically be taught literature. It is true that, as Alvstad points out, "all texts (including those to be found in newspapers, magazines, history books, songs, advertisements, etc) can help develop linguistic competence and can serve as points of entry into foreign culture"[38]. However, unlike newspaper articles, literature has multiple layers of meaning and therefore furthers group analysis and debate. Teaching literature "stimulates the imagination of students and develops their critical abilities"[39]. Students may become so involved in interpreting the different symbols and meanings found in the text that they become eager to master the language in which it was written too. They "become more productive and adventurous when they begin to perceive the richness and diversity of the language they are trying to learn and begin to make use of some of the potential themselves"[33].

Culturally and linguistically, the Arabic language is so different from English that there are not many methods available to teach the Arabic culture to Western learners. The study of literature is the best method by which students can 
dive into the cultural expression of the language and better grasp these aspects via imagery and metaphors. Another method may be to study film and song as well, however these are limited due to their comparatively recent production dates. This is why meaningful or amusing literary texts are "... more likely to have a long-term and valuable effect upon the learners' linguistic and extra linguistic knowledge...." [33].

Exposure to literary works helps students expand their language awareness and develop their language competence. It provides them with specific examples of how language is used. Reading literature helps students familiarise themselves with many features of the written language such as the formation and function of sentences, the varieties of possible structures or the different ways of connecting ideas[40]. It also allows students to acquaint themselves with the lexical and grammatical categories of the target language that shape how its speakers conceptualise the world around them. It shows them elements of culture-specific systems of meaning, value and association in context. A clear example of this is the use of metaphors in poetry or prose. Metaphors "... have been analyzed as providing conceptual schemata through which we understand the world...."[29]. The Arabic sayings below are good examples of culture-specific associations and symbolic meanings:

\section{بالصيف ضيعت اللبن}

Literally: "you lost the buttermilk in summer". Th is is said to someone who has lost a great opportunity as a result of his or her own doings.

\section{كرم حاتم الطائي}

"The generosity of Hatam al-Ta' 'i". This saying refers to the tribe of $\mathrm{Ta}$ 'i; one of the old Arabic tribes famous for its generosity to guests and visitors.

إذا سقطت السماء بأرض قومر عيناه و إن كانو ا غضابا

Literally: "If the sky falls onto people's land, even if they are angry, it will be shepherded". This means that if rain falls onto any land, even infertile land, it will turn it green.

A deeper understanding of other cultures gives students “....respect for differences as well as acknowledgement of similarities...."[41]. The increased information about the culture of the target language obtained through the study of foreign literature will further assist the students to develop their awareness and empathy towards that culture.

However, some educators choose to omit literary works fro $m$ their foreign-language curriculu $m$, not because they do not understand the benefits of such teaching methods, but because they are uncomfortable in presenting the information. They are overly concerned with cultural sensitivity and feel that the culture of another region may spark great controversy. Indeed, in order to fully master a language, many students and educators alike have deeply rooted stereotypes that they will have to overcome. For example, North Americans have been notoriously stereotyped in the Arab world as having a great level of immorality. A presentation of some literature fro $m$ that area may be seen as offensive or obscene. As a teacher of English as a second language to Arab students proclaimed, "If we wish our students to see beyond their stereotypes of North American culture, we need to see beyond our own stereotypes of the culture"[41]. Th is could be a big is sue for some educators. Nevertheless, if a student is to communicate effectively with a person from that culture, they will have to overcome these obstacles, and their understanding must go beyond the harboured stereotypes. Or, as aptly put here, "only when one understands a country's culture is one able to participate in that culture"[41]. To speak the language of a culture is to participate in it.

This is specifically important when studying Arabic literature, as students from the English-speaking Western part of the world may have a highly biased perception of the Arab-speaking Middle East. This region has generally received negative media for the past two decades. However, once a student has gained the ability to read modern Arabic literature, he or she may cast aside such exaggerations or generalisations. Most modern Arabic literature is penned by authors who now face the consequences and potential repercussions of modern political thought and belief within the region. Furthermore, even confining one's reading to only classic Arabic literature will help to explain the history of the Middle East, as for most of its history such literature remained tied to either Islam or the ru ling courts. Hence this makes the study of the literature an interdisciplinary endeavour.

Literature can play a vital role in helping foreign-language students " . . become familiar with many different linguistic $f$ or ms, commun icative fun c t i o n s, and meanings...." [33]. There are however a number of pitfalls foreign-language teachers should be aware of. Many students believe literature is difficult and uninteresting [42]. As a consequence, they are negatively disposed toward it from the outset. Furthermore, if students are asked to engage with literary texts that are beyond their level of linguistic competence, there is a risk that they will lose confidence in their linguistic ability and become demotivated (ibid). This, however, very much depends on the group of students.

The author found that her students were motivated to memorise the verses of the Mu'allaqāt (neves, تاقلعمال) long poems from the pre-Islamic era, even though they were written in language that was far beyond their linguistic ability. The seven poems, each by a different author, are known as "The Suspended Odes" or "The Hanging Poems" because by tradition they were hung on the wall of the Kaaba in Mecca. The author's students were keen to understand the symbols and meanings in the text and so challenged themselves to rise to the level of comple xity of the language. Studies of teaching Arabic as a fore ign language found that the main reasons for students failing to comprehend literary texts were poor preparation by educators, inappropriate teaching strategies and overly ambitious curricula[27]. Experienced language teachers know that no two groups of students are the same and choose texts that are appropriate to the group's linguistic ability and specific interests.

Provided the selected texts are appropriate, then, exposure 
to literary works can help foreign-language students expand their language awareness and develop their language competence. One of the major functions of teaching literature in the foreign-language classroom, however, "is to serve as a medium to transmit the culture of the people who speak the language in which it is written"[15]. Foreign accounts of a culture generally provide an outsider's perspective that may be at odds with the self-perception of the members of a cultural community. Language textbooks are specifically written for foreign-language students and, therefore, present students with a limited and external perspective on the target culture. Literature, on the other hand, is generally written by and for native speakers of the language and is, for this reason, widely regarded as being a source of "genuine" and "authentic" information about the target culture[40].

Unlike purely informative texts, such as newspaper articles, literary texts give students access to “... a world of attitudes, and values, collective imaginings and historical frames of reference that constitute the me mory of a people or speech community...."[27]. They present students with colourfully created fictional worlds that reflect the cultural codes and preoccupations of the language community fro $\mathrm{m}$ which they spring. By actively engaging with these texts, readers come to understand how the characters in such literary works experience the world and how they speak and behave in different settings. As Gray points out, "students learn to see a world through another's eyes, observing human values and a different kind of living, and discovering that others live in very different societies. They will understand and become b roadly awa re of the social, political, historical, cultural events happening in a certain society"[43]. Arabic's rich literary corpus, spanning the pre-Islamic era to the present day, provides students with the opportunity to gain direct unmed iated access to historic and contemporary cultural artifacts. It is the author's experience that teaching this literature to students greatly boosts students' level of engagement and motivation. The Arabic poetry verses below are good examples of culture-specific genuine and authentic information from Majnoon and Laila (مجنون ليلى):

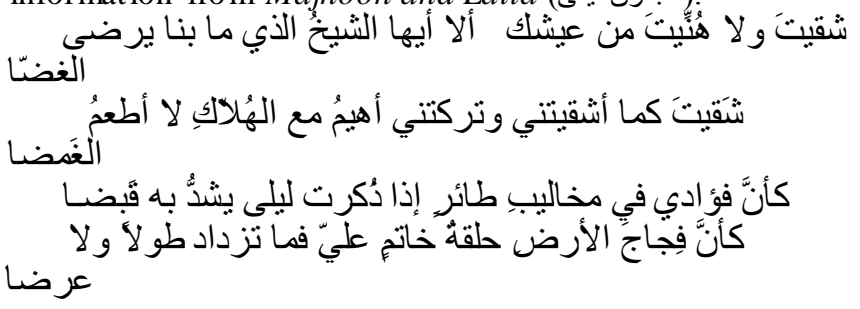

"Oh, Old man who rejected my proposal I hope that you have lived hard life. Like the One you have imposed on me and left me wondering to perish without enjoying my sleep.

It is like my heart captured by a flying bird's claws whenever I mention Laila's name, it digs deeper in my heart. Life on earth is like a ring put on me which does not extend in length and width."

Literature can help students quickly develop a feel for the cultural norms and expectations of the target culture[33]. However, as discussed, if students are to understand and empathise with the cultural logic of the target community it is necessary that they first become aware of the fact that their own beliefs, values and perceptions are shaped by their own native culture. Only when they appreciate the limitations of their own cultural identity, that is, only when they understand that their way of perceiving the world is not universal, can they meaningfully start to interpret and account for the values, assumptions, and beliefs that permeate the literary texts of the target culture[14].

The course is presented using social context and cultural background and by no means can one escape the Is lamic and political influences on any taught topic and genre. The pre-Islamic era lacked the Islamic ideology, but it did not lack religious influence. This society represented power and wielded influence on the Arabian Peninsula and the pilgrimages to Mecca before Islam. During the eras that followed, Is la mic thought and ideology influenced the entire Islamic empire from the East to the West, contributing to large scale division and turmoil in the region.

Arabic literature reflects the values, beliefs, perceptions and preoccupations of the era and geographical region in which it was written. The arrival of Islam had a significant impact on the customs and traditions of Arabs, although some elements of this culture remained unaffected. For example, whereas views on premarital relations changed, the symbolic significance of horses stayed constant. Teaching literature is a great springboard for cultural comparison and raising students' awareness of both the target culture and their own. It is also a great tool for analysing the ways in which language and social variables, such as sex, age, social class or location, interpenetrate. Straub suggests, for example, that students be encouraged to speculate on the social status, group membership or approachability of literary characters by examining the symbolic meanings of the words used to describe them[31]. He recommends that students contemplate "... the significance of various styles of clothing, the symbolic meanings of colours, gestures, facial expressions and other nonverbalcues..." mentioned in literary texts and reflect on whether they concur or are at variance with, those in their own culture[31]. Guided by the author, students examined the influence of environment on the style of poetry and prose with great enthusiasm, comparing the works of Arabic authors from different regions such as Syria, Persia and Andalusia. Active engagement with literary texts raises students' awareness of their own cultural assumptions and helps them appreciate the significance of a particular term or word in the target language and culture.

As Carter and Long point out, “... teaching literature enables students to understand and appreciate cultures and ideologies different from their own in time and space, and to come to perceive traditions of thought, feeling and artistic form within the heritage the literature of such cultures endows...."[37]. When done well, teaching literature in the foreign-language classroom enables students to obtain "a higher degree of intellectual objectivity"[31] when interpreting and seeking to understand the target culture. It 
is a great way to "... combat cultural distance...." [44] and increase empathy with and respect for the language community.

\section{Conclusions}

This paper has shown that teaching literature to foreign- language students can help bridge the cultural gap between the students and the target language community. It has demonstrated that language and culture are so closely linked that it is impossible to achieve full fluency in one but not the other. It has argued that in order for students to be able to communicate effectively in their new language they need to gain an empathetic understanding of the target culture and learn to act in accordance with its norms and expectations. This can best be achieved, it contends, through complete cultural immersion. The paper has highlighted that literature offers students a cost-effective method of doing so. Unlike textbooks or other outsider accounts, literature is written by and targeted at native speakers of a language. It offers therefore an authentic and genuine window upon the culture of the target language. It shows students specific cultural symbols, values and meanings in context and provides them with direct and unmediated access to the thought patterns, judgments and preoccupations of a people at a particular time and place. Furthermore, literature shows how language and social variables interact and also provides students with examples of social roles and expected behaviour in various circumstances. Literature has multiple layers of meaning and therefore lends itself perfectly for critical reflection and debate. Unlike purely informative te xts, literature stimu lates the imag ination and critical abilities of students. It is the author's experience that studying literature greatly motivates students and gives them a heightened sense of achievement.

The paper has argued that the methodology adopted when teaching literature as part of a foreign-language course is of the utmost importance. Texts need to be carefully selected to meet the needs, motivation, interests, cultural background and language level of the students. This does not necessarily mean that students cannot be presented with texts that are above their level of linguistic competence. The author has found that the richness of meaning encountered in classic Arabic texts motivated students to rise to the level of the comple xity of the language. A well chosen literary text, then, can strongly motivate students to engage proactively with the language.

When teaching literature, educators should help students develop the intellectual objectivity required to make sense of the cultural phenomena encountered in the text. They should aim to raise students' awareness and understanding of what it means to be part of the culture. It is vital that students come to understand that they themselves are products of a particular culture and that their background shapes the ways in which they make sense of the world. This is an important job for all foreign-language teachers, but perhaps even more so for teachers of Arabic as a foreign language. By enabling students to directly experience Arabic culture as it is written in literary texts, teachers of Arabic can go a long way to counter the generally negative and often hostile accounts of this culture given by Western commentators. Educators should take a proactive role as cultural mediators and highlight aspects of the literary te xt that are important from an Arabic perspective, and help students make connections between their own culture and the one they encounter in the text. Foreign-language teachers can do no better than to allow the richness and beauty of a culture speak for itself through works of prose and poetry.

\section{REFERENCES}

[1] Hymes, D. 1972. 'Introduction.' In Courtney B. Cazden, Vera P. John and Dell Hymes (Eds.) Functions of Language in the Classroom. New York: Teachers College Press.

[2] Kitao, K. 1991. 'Teaching Culture in Foreign Language Instruction in the Unites States'. Doshish Studies in English; n52-53 p 285-306.

[3] Alptekin, C. 2002. 'Towards intercultural communicative competence in ELT.'ELT Journal 56 (1), 57-64.

[4] Ferguson, C.H. 1959. 'Diglossia,' Word 15: 325-340.

[5] Somech, S. 1980. The Problem of Language in Modern Arabic Literature. Teaching contemporary Arabic Series. Tel Aviv: Ministry of Education and Culture, Curriculum Center, Tel Aviv University.

[6] Kramsch, C. 1993. Context and Culture in Language Teaching. Oxford: Oxford University Press.

[7] Thanasoulas, Dimitrios, 2001. 'The Importance of Teaching Culture in the Foreign Language Classroom'. Radical Pedagogy, No. 3, 2001

[8] Fairclough, N. 1989. Language and Power. London: Longman.

[9] Bourdieu, P. 1990. The Logic of Practice. Stanford: Stanford University Press.

[10] Salzmann, Z. 1998. Language, Culture and Society. An Introduction to Linguistic Anthropology. USA: Westview Press.

[11] Sapir, E. 1921. Language. An Introduction to the Study of Speech. Printed in the USA: Harcourt, Brace and Company.

[12] Peck, D. 1998. Teaching Culture: Beyond Language. Yale: New Haven Teachers Institute.

[13] Durkheim, E. 1947. The Elementary Forms of the Religious Life. Glencoe: The Free Press.

[14] Killick, D. \& Poveda, J. 1997. Perceptions of Cross-Cultural Capability: Is EFL Another Language? Proceedings of the conference at Leeds Metropolitan University, 15-16 December 1997.

[15] Valdes, J. M. (ed.). 1986. Culture Bound: Bridging the 
Cultural Gap in Language Teaching. Cambridge: Cambridge University Press.

[16] Landar, H. 1965. Language and Culture. USA: Oxford University Press.

[17] Howell, W. R. \& Vetter, J. H. 1976. Language in Behaviour. New York: Human Sciences Press.

[18] Byram, M., Morgan, C. and Colleagues. 1994. Teaching and Learning Language and Culture. Great Britain: WBC.

[19] Lado, R. 1964. Language Teaching: A Scientific Approach. New York: McGraw-Hill.

[20] Politzer, R. 1959. Developing Cultural Understanding through Foreign Lan guage Study. Report of the Fifth Annual Round Table Meeting on Linguistics and Language Teaching, pp. 99-105. Washington, D.C.: Georgetown University Press.

[21] Lessard-Clouston, M. 1997. 'Towards an Understanding of Culture in L2/FL Education'. In Ronko, K.G. Studies in English, 25, 131-150 Japan: Kwansei Gakuin University Press.

[22] Fowler, R. 1986. Linguistic Criticism. Oxford: Oxford University Press.

[23] Armour-Thomas, E. \& Gopaul-Nicol, S. 1998. Assessing Intelligence. Applying a Bio-Cultural Model. USA: Sage Publications.

[24] Duranti, A. 1997. Linguistic Anthropology. Cambridge: Cambridge University Press.

[25] Tannen, D. 1979. 'What's in a Frame? Surface evidence for underlying expectations'. In Freedle, R. O. (ed.). New Directions in Discourse Processing. Vol II in the series Advances in Discourse Processes. Norwood, N. J.: Alex.

[26] Samovar, L., Porter, R. \& Jain, N. 1981. Understanding Intercultural Communication. Belmont, CA: Wadsworth.

[27] Kramsch, C. 1988. 'The Cultural Discourse of Foreign Lan guage Textbooks'. In Singerman, A. (ed.). 1988. Toward a New Integration of Language and Culture. Northeast Conference reports 1988. Middlebury, Vermont: Northeast Conference.

[28] Huebener, T. 1959. How to Teach Foreign Languages Effectively. New York: New York University Press.

[29] Singhal, M. 1998. 'Teaching Culture in the Foreign Language Classroom'. Thai TESOL Bulletin, Vol. 11(1), February 1998.
[30] Melde, W. 1987. Zur Integration von Landeskunde und Kommunikation im Fremdsprachenunterricht. Tubingen: Gunter Narr Verlag.

[31] Straub, H. 1999. 'Designing a Cross-Cultural Course'. English Forum, Vol. 37( 3), July-September, 1999.

[32] Tavares, R. \& Cavalcanti, I. 1996. 'Developing Cultural Awareness in EFL Classrooms'. English Forum, 34(3), July-September, 1996.

[33] Hişmanoğlu, M. 2005. 'Teaching En glish through Literature' Journal of Language and Linguistic Studies 1(1): 53-65.

[34] Jalling, H. 1968. Modern Language Teaching. London: Oxford University Press.

[35] Duff, A. and Maley, A. 1990. Literature. Oxford: Oxford University Press.

[36] Brumfit, C.J. \& Carter, R.A. 1986. Literature and Language Teaching. Oxford: Oxford University Press.

[37] Carter, R.A. \& Long, M.N. 1991. Teaching Literature. London: Longman.

[38] Alvstad, C. and Castro, A. 2009. 'Conceptions of Literature in University Language Courses.' Modern Language Journal 93 (2): 170-184.

[39] Lazar, G. 1993. Literature and Language Teaching: A guide for teachers and trainers. Cambrid ge: Cambrid ge University Press.

[40] Collie, J. \& S. Slater. 1987. Literature in the Language Classroom: A resource book of ideas and activities. Cambridge: Cambridge University Press.

[41] Gholson, R. \& Stumpf, C. 'Folklore, Literature, Ethnography, and Second-Lan guage Acquisition: Teaching Culture in the ESL Classroom' TESL Canada Journal 22(2): 75-88.

[42] Chandrasenda, N. 2007. 'Integrating Literature into Foreign Language Teaching: A Sri Lankan Perspective' . Novitas ROYAL 1(2): 92-97.

[43] Gray, R. 2005. 'Using Translated First Language Literature in the Second Language Classroom The Internet TESL Journal, 11(12), 1-3.

[44] Swaffar, J. 1992. 'Written Texts and Cultural Readings'. In Kramsch, C. and McConnell-Ginet, S. (eds.). 1992. Text and Context: Cross-Disciplinary Perspectives on Language Study. Lexington, MA: D.C. Heath. 